Folque, M. A. \& Siraj-Blatchford, I. (2011). Fostering communities of learning in two Portuguese pre-school classrooms applying the Movimento da Escola Moderna (MEM) Pedagogy . International Journal of Early Childhood, 43.

\title{
Fostering communities of learning in two Portuguese pre-school classrooms applying the Movimento da Escola Moderna (MEM) pedagogy.
}

\author{
Maria Assunção Folque \\ Professora Auxiliar no Departamento de Pedagogia e Educação, Universidade de Évora \\ Tel: +351266 768050 \\ Fax: +351 266768073
}

Email: mafm@uevora.pt

Iram Siraj-Blatchford

Professor at Institute of Education, University of London

Tel: $+44(0) 2076126218$

Fax: $+44(0) 2076126230$

Email: i.siraj-blatchford@ioe.ac.uk

\begin{abstract}
This paper reports upon a Portuguese pedagogical model, where children engage with the teacher in planning and assessment during routine activities like "Council Meetings", "Communication Time", and using specific tools such as an "Activities Chart" and a "Diary". The paper questions how these processes generate a community of practice in 'learning to learn' with children aged 3 to 6 .
\end{abstract}

The study developed a theoretical framework using socio-cultural theory where action is mediated through the use of artefacts/tools and the communities' social structures: roles, rules, division of labour and access to resources (Lave and Wenger 1991). This literature was complemented by a study of the children's "learning to learn" which provided a focus on specific learning objects (meta-learning and learning dispositions such as learning orientation).

Two pre-school classrooms were studied over one year using observations, video recordings, interviews with teachers and children, and analysis of two piloting tools: the "Diary" and the "Activity Chart". Both classrooms provided "communities of learning" where children were encouraged to self-regulate their learning and engage in collaborative activities, transforming their leading activity from playing with others to learning with others (Siraj-Blatchford 2007). Despite these general results, each classroom produced a distinctive learning culture rooted in the individual teachers' knowledge and control of the classroom community and interactions.

Résumé L'étude concerne un modèle pédagogique portugais où les enfants s'engagent avec
l'enseignant dans la planification et l'évaluation au cours d'activités de routine telles que les "Réunions du
Conseil" et le "Temps des Communications", en utilisant des outils spécifiques tels que le "Tableau des
Activités" et le "Journal". Cet article questionne la façon comment ces processus génèrent une communauté
d'"apprendre à apprendre" avec des enfants âgés de 3 à 6 ans.
L'étude a élaboré un cadre théorique en utilisant la théorie socio-culturelle où l'action est médiatisée par
l'utilisation d'objets / outils et par les structures sociales de la communauté: les rôles, les règles, la division du
travail et l'accès aux ressources (Lave et Wenger, 1991). La littérature sur "apprendre à apprendre" complète la
théorie socio-culturelle en offrant un focus sur des objets spécifiques d'apprentissage (méta-apprentissage et les
dispositions telles que les but d'apprentissage).
Deux salles de classe préscolaire ont été étudiés pendant un an à partir d'observations, d'enregistrements vidéo,
d'entrevues avec les enseignants et les enfants, et de l'analyse de deux outils de pilotage: le "Journal" et le
"Tableau des Activités". Les deux salles présentent des "communautés d'apprentissage" où les enfants ont été
encouragés à autoréguler leur apprentissage et à s'engager dans des activités de collaboration, transformant ainsi
leur activité phare de jouer avec les autres en apprendre avec les autres (Siraj-Blatchford 2007). En dépit de ces 
résultats généraux, chaque classe a produit une culture d'apprentissage différente, enracinée dans la connaissance individuelle de l'enseignant ainsi que dans le contrôle de la communauté et des interactions en classe.

Resumen El documento describe un modelo pedagógico portugués donde el maestro y los niños realizan juntos la planificación y la evaluación durante actividades de rutina como las "Reuniones de Consejo" y el "Tiempo de Comunicaciones" usando herramientas específicas tales como el "Plan de Actividades" y el "Diario". Este trabajo cuestiona la forma cómo estos procesos generan una comunidad de "aprender a aprender" con niños de 3 a 6 años.

El estudio desarrolló un marco teórico utilizando la teoría socio-cultural donde la acción está mediada a través del uso de artefactos/instrumentos y estructuras sociales de la comunidad: roles, reglas, división del trabajo y el acceso a los recursos (Lave and Wenger 1991). La literatura sobre "aprender a aprender" complementa la teoría socio-cultural proporcionando un enfoque específico sobre objetos de aprendizaje (meta-aprendizaje y el aprendizaje de disposiciones tales como la orientación de metas de aprendizaje).

Se estudiaron dos clases de preescolar durante un año a partir de observaciones, grabaciones de vídeo, entrevistas con los maestros y los niños, y el análisis de dos herramientas de pilotaje: el "Diario" y el "Plan de Actividades". Ambas clases dieron lugar a "comunidades de aprendizaje" donde los niños fueron animados a autorregular su aprendizaje y a participar en actividades de colaboración, transformando su actividad principal de jugar con los demás en aprender con los otros (Siraj-Blatchford 2007). A pesar de estos resultados generales, cada una de las clases produjo una cultura distinta dependiente del saber individual del maestro como también del control de la comunidad de la clase y de las interacciones.

Keywords: Communities of Learning; learning to learn; planning and assessment; preschool; pedagogy.

\section{Introduction}

In classrooms operating as Communities of Learning, children take an active role in steering their own learning.

Children's involvement in planning and evaluation promotes meta-learning and empowers students as selfreliant learners (Puluyanov and Matiss 1999; Watkins 2005). Such practices have been highlighted as practices that promote "learning to learn" which is paramount in providing students with the capacity to continue to learn throughout life.

Children's participation in planning and evaluation in their classrooms has been studied mainly in primary schools but also in pre-school. We can trace two lines of research, which contribute to the development of such practices in pre-school. One associates children's participation in decision making (having a voice) with pedagogic quality. This is based on the view of the child as a citizen, and an active member of a democratic society based on their ability to contribute to the common good (i.e. Sheridan and Pramling 2001). The second considers children as learners and links children's participation in planning and evaluation with developing learning dispositions. The plan-do-review cycle of the High-Scope curriculum, provide opportunities for children to reflect on their process of learning by planning in advance what to do and reviewing what they have done, evaluating and bringing to consciousness the process of learning. Such planning and reflection dialogues are vital to changing aspirations which are "the real engine of change" (Sylva 1992, p. 141) as they provide “cultural tools for mastery" (op cit: p. 146).

Research evaluating the impact of pedagogical models (inputs) and children's learning or development (outputs) tell us little about the processes occurring in everyday classrooms which contribute to making a difference in 
children's learning trajectories. This study contributes by studying in depth the processes of planning and evaluating with young children from 3 to 6 years old in a particular learning context, and how these contribute to the expected goals. We are interested in the structural and in the interactive aspects of the learning process and in the cognitive benefits it offers children (Edwards 2005). Describing the processes that occurred in two classrooms applying the same pedagogic model we hope to show the way by which some components of the model are contributing in developing communities of learning; at the same time particular components of each classroom learning culture can have a different effect on the ability to help children learning to learn. Therefore, this study considers the sociocultural context in which learning occurs (see section on theoretical background).

The Movimento da Escola Moderna (MEM) is a teachers' movement in Portugal which applies a pedagogical model, wherein children actively participate in planning and assessment together with the teacher during regular daily and weekly activities such as "Council Meetings" and "Communications Time", using specific piloting tools such as the "Activities Chart" and the "Diary".

Our questions in studying this model implemented in two Portuguese preschool classes, were: How do young children participate in planning and evaluating in their classrooms? How does participation in planning and evaluating activities using the piloting tools, promote children's learning to learn?

\section{Background}

The MEM has three broad educational aims: Initiation to democratic practices; re-institutionalisation of values and social meanings and cooperative reconstruction of culture (Niza 1996). The three aims of MEM focus on the personal and social development of teachers and students as active, democratic citizens as well as on their cultural development. Learning is seen as an empowering process, which provides tools for autonomous and responsible citizens to actively engage in and act in the world with solidarity and personal and social fulfilment.

Children in MEM pre-school classrooms start every day with a "Council Meeting" to welcome each other and plan the day and week; after this whole group activity they move on to "Activities and Project Time" in specific areas of the classroom. After break, the group gets together for "Communications Time" where children present their work to the whole class group. The afternoon is devoted to cultural activities: story-telling and drama, cooking, correspondence, music and dancing and visits from invited guests such as parents and people from the community. The day ends with another "Council Meeting" where the group revisits what they have done and starts to set up activity goals for the next day. Throughout the day, teachers and children make use of specific piloting tools to help to steer/regulate what is happening in the classroom (individually and as a group) and to document their group life. The piloting tools include the "Attendance Chart", the "Diary", the "Activities Chart", 
the "Social Rules Chart", the "Responsibilities Chart" and the "List of Projects". MEM pre-school classrooms include children of different ages and abilities (3-6 years old) to enrich the child's experience both socially and cognitively, in an inclusive and diverse group (Niza 1996).

In this paper we focus on three aspects of the MEM model, which concern planning and evaluating activities particularly relevant to children's learning to learn: the "Council Meetings" using the "Diary"; the use of the "Activities Chart" and "Communications Time".

\section{The Theoretical Framework}

Our theoretical framework we employ combines sociocultural theory with a concern for children's learning and cognitive development (Edwards 2005). According to sociocultural theory, action is mediated through the use of artefacts/tools and the community social structures: roles, rules, division of labour, and access to resources (Lave and Wenger 1991; Vygotsky 1978; Wertsch 1998). The literature on learning to learn complements sociocultural theory providing a focus on specific learning objects - meta-learning and learning dispositions as learning orientation.

Using this theoretical background (Figure 1) our analysis focuses on both the social processes of teaching/learning mediated by cultural tools (applications of the MEM model) as well as on the learning of cognitive and motivational processes generated within pre-school classrooms.

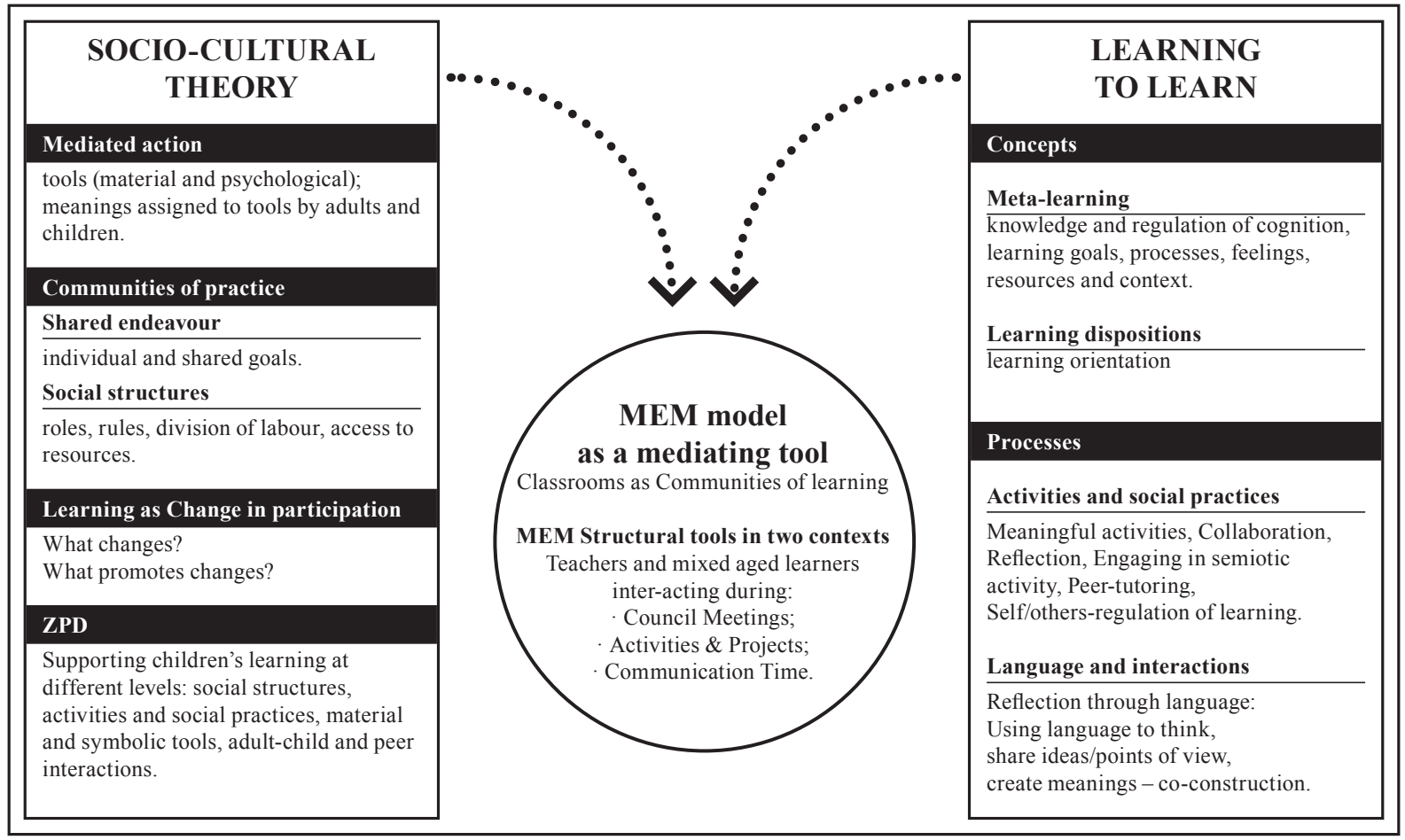

Fig. 1 Theoretical and Analytical framework for bringing together sociocultural context and learning 
Drawing from literature on communities of practice, the classrooms were investigated as communities of learners, understanding learning as a shared endeavour (Wenger 1998). Learning is conceptualised as transformation in participation in social practices (van Oers 1999; Carr 2001; Rogoff 1998) and the analysis focused on how changes occurred in relation to the participants roles, identities, power, responsibility, goals and commitment to learning as well as control over learning.

The focus on learning to learn directed our concern with children's change in participation in the processes associated with meta-learning and learning dispositions such as learning orientation. Meta-learning refers to gaining control of the processes of learning including knowledge and regulation of cognitive processes, reflection on goals, feelings, social relations and the context of learning (Watkins 2001). Learning to learn entails also a transformation in learning dispositions (Claxton 2002). We used the concept of learning orientation and the work of Dweck $(1986 ; 2000)$ which has shown that children can display, from a very young age, different attitudes towards learning, whether learning oriented or performance oriented. Being learning oriented means showing interest in the processes of learning (mastery oriented) whereas to be performance oriented is to be concerned with the final result or product (helpless). In face of difficulty, helpless learners are not persistent and give up easily as they usually worry about their lack of ability; whereas mastery oriented learners focus on effort and strategies instead of worrying about incompetence.

\section{Methodology}

This research was part of an extended study (Folque, 2011, in press) based on two pre-school mixed age classrooms (3 - 6 years) applying the MEM model. One had 23 children and the other 18 . The teachers were selected for their proficiency in the MEM pedagogy. The design used case studies with ethnographic elements, over a period of one school year to study in depth, the processes of learning and teaching, including planning and evaluation with young children.

The data for the study includes: field notes of observations of children and teachers inter-acting in planning and evaluation activities; video recording of group activities such as "Council Meetings" (one Monday CM and one Friday CM per month) and "Communications Time" (one per month); Interviews with teachers and children (about the activities and the piloting tools) and analysis of piloting tools: "Diaries" (two per month) and "Activity Charts" (one per month).

The interviews where conducted with same age pairs of children using photographs of the "Council Meetings" and "Communications Time" as well as the "Activities Chart" and the "Diary" to prompt children's 
understandings of these activities and tools, their goals/purposes, the role of adults and children and the rules for action (Folque 2010).

We conducted some quantitative analysis concerning the participation patterns of children in both activities and piloting tools. An in-depth analysis of the inter-action processes - what participants did and how they interact during the activities and the use of the piloting tools focused on the actions and configuration of the activities, the roles of the participants and its rules. Transcripts of dialogues were also systematically interrogated in the NVivo software in terms of meta-learning components and children's learning orientation. This theoretically driven analysis mapped the social structure of the activities and the children's change in participation. This analysis was complemented by an emergent grounded analysis which provided specific elements of the culture of learning created in each classroom.

\section{Findings}

We will present the findings using analysis of three activities: "Council Meetings" using the "Diary", the “Activity Chart" and "Communications Time". In each of these activities there is an account of what they do, teachers and children' perceptions of the activity, roles and participation patterns and inter-actions focusing on meta-learning, learning orientation and learning culture.

\section{"Council Meetings" using the "Diary"}

The "Council Meeting" (CM) is a whole-group language-based activity where children participate in the decisions about the curriculum through planning and evaluating. Planning is a negotiated process emerging from the children's individual interests, from the teacher's suggestions, from the needs and interests of the group or from community relevant activities.

The classroom "Diary" (Fig. 2) is a weekly register with four columns: "We liked", "We didn't like", "We did" and "We want". Any child or adult can fill in the "Diary" at any time during the week. Children can draw or ask an adult or older child to write for them, and the child can illustrate this. In the "We liked" and "We didn't like" columns children register positive or negative incidents of group-life focused on attitudes and behaviours. Each day the group uses the "Diary" to plan (We want) and to evaluate (We did) the activities and projects and, at the end of the week, during the Friday CM the "Diary" is fully discussed and analysed. 


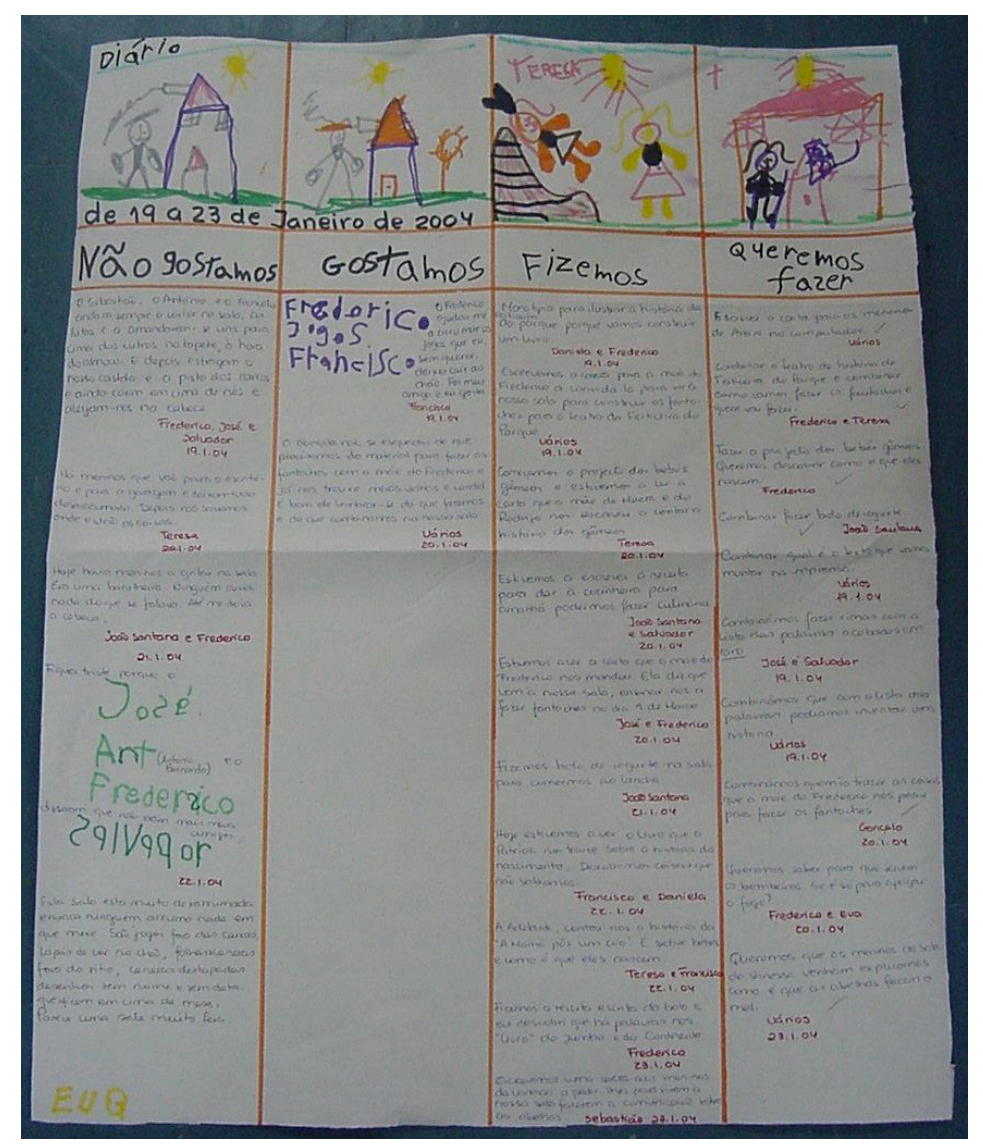

Fig. 2 The "Diary"

Through participation in planning and evaluation at CMs, the children learned to move from just choosing what to do into thoughtful planning in accordance with negotiated goals, taking into account the context in which to work (when, where, with whom, how). They learned to reflect on what they had already done and to apply those reflections in designing new negotiated plans, in a continuous cycle of evaluation, planning (we want) and back to evaluation.

Through whole group interactions during CMs the children appropriated the project conduct which some children started to apply autonomously during "Activities and Project Time". This framework promoted engagement in reflection about "What do we want to do/know?" "What do we already have/know?" "How can we do /find out what we want?" "Who is going to do it and when?" "What have we done and how?" and was embedded in many of the interactions between the teachers and the children. Children's meta-learning statements increased in both classrooms throughout the year.

The children's ability to engage in devising thoughtful plans in CMs was related to the teacher's ability to provide adequate challenges and to support them. This support was particularly efficient when the teacher understood and respected the children's line of thought and their difficulties, and was able to engage in more "sustained shared thinking" to extend their ideas (Siraj-Blatchford et al. 2002). 
According to both teachers the CMs had two central goals: planning and evaluating together, and learning to live in a community. However the children in the two classrooms differed in their perceptions of what CMs were. In Amoreira, children viewed CMs as a place 'to solve problems' and 'to show, tell or write a text' while in Magnólia children viewed CMs as the place 'to see who behaved and who misbehaved' and to 'see what we're going to do'.

In both classrooms the Friday CM included reading the "Diary" columns to evaluate the week. Although the two classrooms carried out this activity differently: In Magnólia, all the columns of the "Diary" were read and discussed and a summary of the evaluations and group decisions was recorded on the "Meeting Minutes". In the Amoreira classroom, usually only the two first columns were discussed, focusing the Friday CM on exploring the positive and negative incidents of the week. Evaluation and planning of the activities was frequently postponed until Monday CM to make more time for thoughtful discussion.

Elements of the teacher's pedagogy were found to be critical for the progress children made in their personal and social development. Their attitude was paramount in holding a neutral approach towards the children involved, supporting the child under "criticism" so that he/she did not feel accused as a person, encouraging a supportive but critical appreciation of the event, and respecting children's feelings and not imposing a quick resolution to the problem.

In Amoreira such factors lead to a clear improvement in children's ability to discuss behaviour without discussing a person's value, and understanding the role of the group as a supportive one in solving their problems. In this way children's disposition to persist in the face of difficulty was fostered. On the other classroom the simple repetition of general statements and rules, and an emphasis on good or bad behaviours focusing on general, evaluative comments rather than descriptive ones, as well as on personal traits rather than behaviours, was seen to promote performance-oriented attitudes in children and to weaken their ability to persist when facing learning challenges. Children's collaborative versus disputative behaviours during activities evolved steadily in Amoreira but in Magnólia there was a shifting pattern.

Differences in the way CMs were run in each classroom were related to contextual variables, institutional pressures and the teacher's understanding of the activity. For instance, at the Magnólia, the self-described pressure on the teacher, to keep up to the institution's standards led to some lack of flexibility; The Amoreira teacher, free from such institutional pressures, was able to adjust her practice with the children according to what she felt was appropriate. 


\section{Using the "Activities Chart" as a piloting tool}

After the morning "Council Meetings", children plan and register their individual choices in the "Activities Chart" (AC). The AC is a two-way table with all the children's names on the left column and the activities or working areas menu across the top line. Each child makes a circle in his/her planned activities columns: once the activity is completed they go back and fill in the circle.

Children used the AC as a self-regulative tool on different levels: identifying and choosing activities from an array of possibilities - planning (anticipating) their activities, monitoring plans, reflecting on their choices and progressively engaging in purposeful planning through the appropriation of explicit learning oriented criteria based on assessment.

Despite the AC promoting planning strategies and self-evaluation abilities in both classrooms, there were some differences between the two classrooms with respect to the layout of the AC, the way children understood and used this piloting tool, and children's self-regulatory display of behaviours.

The Amoreira AC (Figure 3) is designed in accordance with the MEM model. In order to help the children to use the AC, the Amoreira teacher added a rules script (Figure 4) displayed beside the AC.

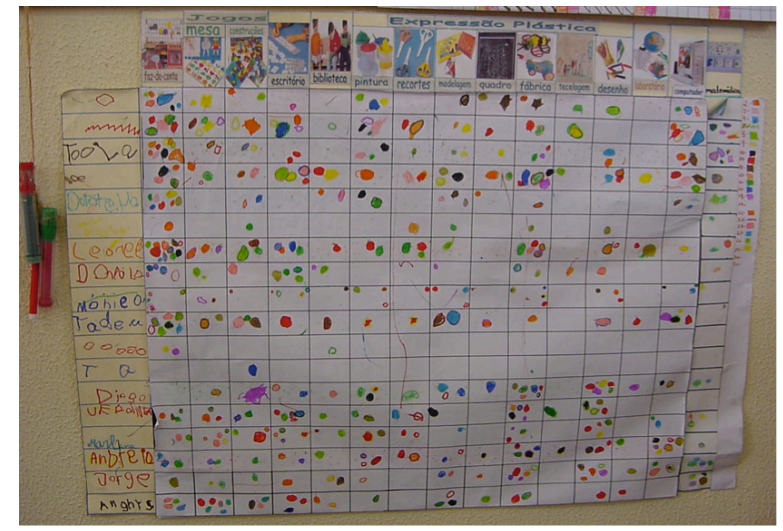

Fig. 3 Amoreira's AC

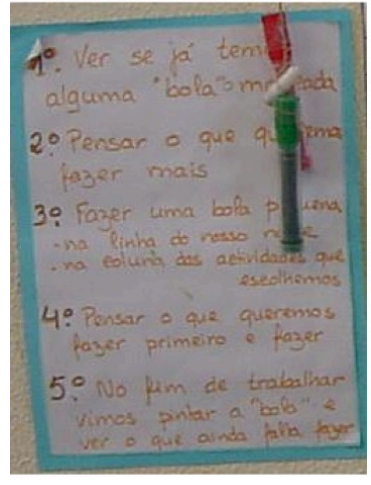

st Seeing if there is any circle marked;

2nd Thinking what else we want to do;

3rd Drawing a small circle

- in our name's row

- in the column of the chosen

activity;

4th Thinking what we want to do first, and do it

5th When finishing work we come to colour the circle and check what else we have to do.

Fig. 4 The AC rules script

The Amoreira AC rules script directed the children both to action procedures and metacognitive processes - selfappraisal (rules 1,2 and 5) and self-management (rule 4 and 5) - inviting children to stop, read the chart and plan what to do next. In this classroom, planning was not left to an impulsive choice, but rather the result of a thoughtful choice based on a cycle of evaluation.

The Magnólia AC was split into two different charts: the "Planning AC" (Fig. 5) and the "Evaluation AC" (Fig. 6). This reconfiguration of the piloting tool, developed within the institution, aimed to simplify the use of the chart for planning and evaluation. 


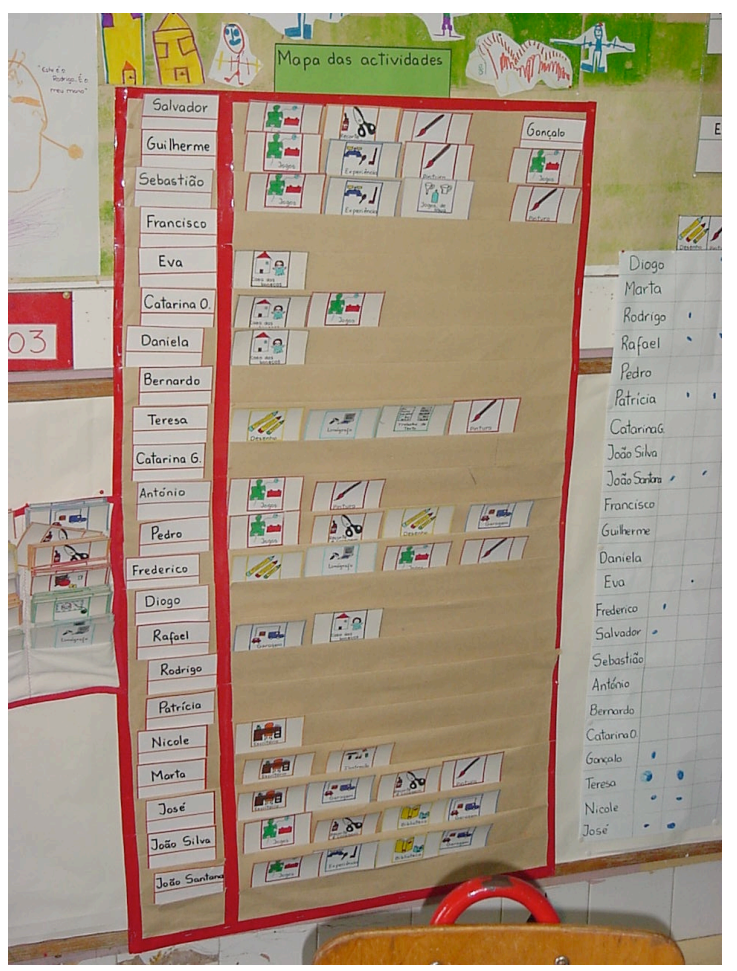

Fig. 5 Magnólia planning AC

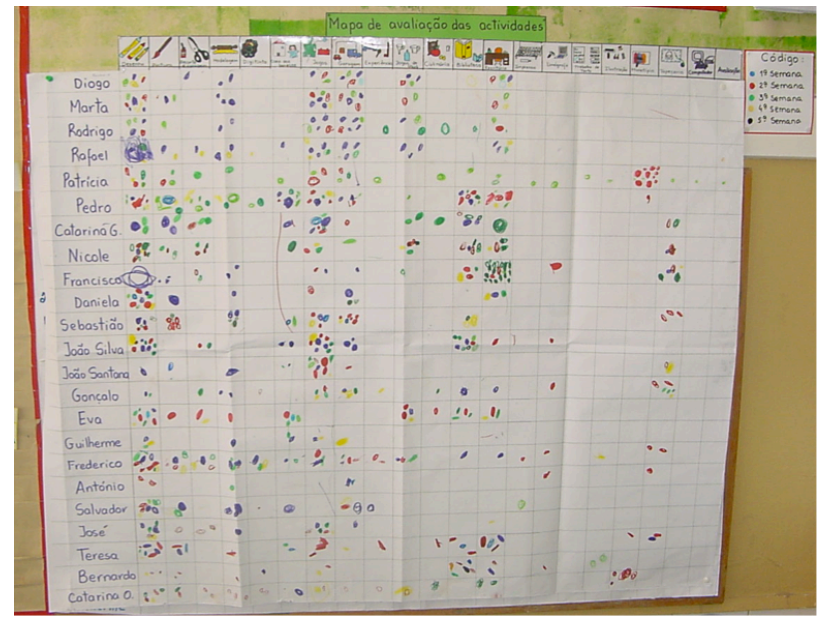

Fig. 6 Magnólia evaluation AC

The design of the Magnólia planning AC afforded children the opportunity to plan and think about the sequence of activities, although it also hindered the possibilities of planning based on evaluation. What seemed (to the preschool team) to be an efficient adaptation of the AC, acted against the processes that this MEM tool is meant to mediate - planning informed by evaluation.

The way in which the AC was used and the meanings that children and the teacher attributed to it, was also a mediating factor in the way this piloting tool accomplished its function.

Differences in the teachers' perceptions and practices of the AC, resulted in a stronger self-regulation of the children's activities in Amoreira, and a weaker one in Magnólia where the teacher believed that children should do what they were interested in, and that planning at the AC should not prevent them from engaging in other activities: Responsibility to stick with individual choices and to venture into areas where they were less experienced was not a priority for the Magnólia children and their teacher although it was in Amoreira.

While some of the oldest children in both classrooms said that the AC would help them to see what they had done, and to plan things they had not as yet engaged in, this process was only observed in Amoreira. Amoreira children actually used this regulative discourse (even the youngest); they helped each other to base their planning on evaluations of the AC, and the oldest (5 years olds) independently planned according to their evaluation needs and learning challenges. None of the youngest children were seen displaying self-regulation in their independent planning but still they were starting to use it with others in peer tutoring. 


\section{"Communications Time"}

"Communications Time" (CT) is a whole-group language based activity where children are invited to revisit their first hand experiences by presenting them to others. The perceived goals of $\mathrm{CT}$ in both communities were centred on two distinct but complementary aims: community building (sharing, celebrating learning) and learning (through listening to their peers, reflection, collaboration and co-construction).

In both classrooms, a common structure of $\mathrm{CT}$ episodes emerged. This structure included different actions in a quasi-fixed order: 1) Showing/telling and describing, explaining; 2) Questioning and commenting; 3) Evaluating; 4) Suggesting ideas for improvement.

These actions structured the development of the activity, the roles of the participants and patterns of participation and, consequently, the learning processes generated. The analysis showed that the basic structure of individual episodes provided children with the opportunity to engage in metacognitive thinking and metalearning, using language and their products to represent their (sometimes emergent) learning activities. As SirajBlatchford (2007) points out,

The development of these sophisticated levels of abstraction (and metaconciousness) also facilitate the development of a wider Metacognition (the knowledge and awareness that children come to develop of their own cognitive process). The metacognition that is so important in learning to learn also develops as the child finds it necessary to describe, explain and justify their thinking about different aspects of the world to others (p.14).

One interesting aspect of $\mathrm{CT}$ is that it provides opportunities for "making learning visible" and, therefore, the object of reflection and dialogue, a crucial condition of learning to learn (James et al. 2006). In both classrooms there was evidence that learning was made visible in terms of different processes, from simple play activities, mostly with a tangible product in Amoreira and goal-oriented activities and more complex processes of inquiry in Magnólia. When children were invited to talk about their activities and products, they did at times engage in meta-learning which included reflection on goals, feelings, social relations and the context of learning which were the object of shared reflection and appropriation by the group. This meta-learning process focused on actions involving simultaneously doing and thinking (cognitive, affective). In the early years though, children are just beginning to understand their actions as learning activities. This was evident on some occasions in CT, and it increased towards the end of the year.

CT was a consistent routine at Amoreira taking place everyday (28 days out of 33) and children would volunteer to present; at Magnólia CT took place only when the teacher decided that there was something important to be 
presented to the group ( 8 out of 36 days).

The rules that determined who was going to make a presentation had particular implications for the activity in each classroom. The children's control of the CT episodes gave rise to an excessive number of presentations at the Amoreira CT, and poor interactions in some episodes as a result of time constraints. In the Magnólia classroom, some children had no experience of presenting at CT and therefore were never given the opportunity to benefit from the role of presenter.

Peer-tutoring was a strong component of CT, although it was understood and realized differently in both classrooms. In the Magnólia classroom, the audience would listen quietly and attentively to the presenter(s) and praise them. Criticism was not encouraged as the presentations were mainly from very "interesting" work. Despite that, the group did often end up in many episodes engaging with the presenters' work achievements, extending and complementing them, and planning future activities. Such follow-up of children's work (although not based on criticism) also provided children with opportunities to stretch their learning with the support of the group. In the Amoreira classroom peer-tutoring included a more interactive process during the "evaluating" part of the episodes, where both the presenters and the audience supported each other, offered critical comments, negotiated meaning and co-constructed new understandings with the critical contribution of all. The analysis showed that when children engaged in group interactions, the opportunities for reflection, experiences of variation of thought and use of mentalistic language and reasoning were enhanced.

\section{Discussion}

The analysis of the processes of learning that occurred while children participated in each planning and evaluation activity permitted us to evaluate the potential of these to promote children's meta-learning and selfregulatory dispositions.

In CMs children in both classrooms moved from choosing what to do to devise more complex plans based on evaluation and considering the conditions to reach to shared goals, what Epstein (2003) calls planning with intention. The meta-learning questions seem to provide children with a meta-learning tool for though. Children did show an increasing use of independent self-regulation statements when working independently, which is linked with the consistency of the project work and the use of the project framework throughout many interactions with the children.

We found that the piloting tools were important in supporting the young children's planning and assessment in varied ways. Their materiality and clarity, combining writing with drawings or pictures, helped very young 
children to use them with ease. Analysis of the interviews with the children revealed they had an impressive understanding of the different piloting tools, how to use them and what their function was in the classroom. The study revealed that the way in which the piloting tools were used and the resulting interactions, were of major importance for the meanings created about the functions of each tool, within its own context.

One aspect that emerged from this study is the importance of linking assessment with planning an essential feature of formative assessment and more specifically of assessment for learning (James et al. 2006).

\section{Assessment for learning}

The assessments for learning processes occurring during CMs and the use of the AC were centred on activities ("what do I need to do or choose") rather than learning content ("what do I need to learn") or processes. However, supported by clear planning criteria some children understood "doing different activities" as a way to learn, meaning that they began to understand learning and the process of knowing as something that arises from intentional action: "we choose different activities so that we can learn to do all these things" (Marlene (5:10) in children's interviews about the AC); according to Pramling (1996) this is already a sophisticated view of learning.

When the children had the opportunity to reflect on what they need (evaluation) to devise plans that respond to children's needs, children from a very young age can start to see themselves as learners and to develop selfregulated behaviours.

When properly supported children also centred assessment for learning processes in "learning to solve problems" rather than "learning to behave" through a comprehensive discussion of the problems registered in the "Diary". Many studies stress the importance of children's learning to solve conflicts through a dialogic process where the adult help children to reflect on what happened and find out ways to solve their conflicts (SirajBlatchford et al., 2002). The MEM use of the "Diary" and the discussion at Friday CMs seem to add-up to an array of positive strategies that can be used in pre-schools. Although, the study of how these dialogues are conducted proved to be necessary to reveal how the meanings where created, how they can promote learning orientation and the general progression of children's social development: the opportunity for all the children to participate in the discussions, analysing the problems without judging the children involved, respecting the children's feelings and cooperatively find ways to overcome problems where vital components of such dialogues.

The evaluation part of CT was of crucial importance for children's learning identities and for their mastery of the process of learning. This action, though, should go beyond celebration of achievements by the community 
and should not act only as general praise. The literature suggests that just praising children is not in itself a positive factor, and in many learning contexts can negatively affect children's learning dispositions (Kamins and Dweck 1999; Dweck 2000). The use of both criticism and encouragement in assessing children's work seemed to provide children with future tools for learning (criteria, strategies) and dispositions to persist in the face of difficulties.

The supportive context of the classroom taking responsibility for individual and group progress was a key factor in the children's progress in learning oriented attitudes rather than helpless. The group dialogues, when encouraged, provided also opportunities for children's increased meta-learning statements. Such finding is in line with research both in pre-school and in primary school (Watkins 2005; Pramling 1996; Larkin 2010).

\section{Structural aspects of the pedagogy}

One aspect that was seen to contribute to children's understanding of the purposes and goals of the activities and the piloting tools, and consequently their full participation, was the consistency of the routine. A common understanding of the goal of the activity is crucial for involvement in meaningful learning activities. The children's views of the activity were related to what they experienced and not, as it might happen with the teachers, with what was supposed to be happening.

The mixed age grouping of these classrooms offered opportunities for children to benefit from a Zone of Proximal Development (ZPD) context progressively including in their repertoires some of the cognitive tools distributed in the classroom learning culture and offering opportunities for peer-tutoring. Such opportunities played an important role in the older children's display of autonomous self-regulatory behaviours.

The rules that structured the activities, created within each class different learning processes and opportunities to learn. These rules arose from the teachers' understanding of the activity but also from the institutional context to which they belong.

Institutional culture - In this study, one of the institutions had a strong leadership devoted to quality, which imposed some practices on the teachers without the support that would help teachers to solve their problems. The teacher felt that there was no space for adjusting practices and wishing to respond to the high standards for products and practices promoted by her institutions, she displayed on some occasions performance oriented attitudes rather than a learning orientation. Watkins points out that when feedback is focused on judgments of teachers' performance in the classroom teachers tend to show performance oriented attitudes, helplessness and defensiveness towards the improvement of their practices (Watkins 2000). 


\section{The teacher's pedagogy}

In many respects, both teachers shared a similar understanding of the activities and the piloting tools. However, they differed in how they perceived, organized and conducted the activity.

One particularly important factor seemed to be the teachers' understanding of the role of assessment and regulation in classrooms. The Amoreira teacher assumed openly the role of assessment and regulation for learning by consistently using the tools for grounding planning on assessment, stating clearly the rules, encouraging critical discussions of presentations in CT or behaviours in CMs as the base for progression. Problems were clearly and deeply discussed with the children helping to overcome them with the support of the group - building up community. In interactions with the children, she used a neutral tone, using encouragement and criticism focusing on behaviours and not making personal judgements. At the same time she was very attentive and understood her role in regulating participation in interactions. The Magnólia teacher used a less clear system of regulation as she did not use the evaluation AC to base children's planning, she did not encouraged children's critical evaluation of CT and the rules for participation in interactions were not clear. In the Magnólia classroom, children who participated were the ones with the ability to put forward their ideas; the Magnólia teacher's understanding that children should not be encourage to participate in activities they were not naturally inclined to do or confident about, failed to promote individual progress. On another hand, when interacting with children she used a more emphatic and more judgmental tone (displaying happiness or sadness) in face of the children's work or behaviours. At times, this led to her task-related feedback being received by the children as personal criticism leading some children to seek her approval or acceptance, and to fear that she would not accept their work (helpless attitudes, performance oriented). This occurred particularly when children misbehaved and when they failed to respond to the high standards that were set for the quality of the products or thinking.

The evaluative system and discourse (what is valued as learning, the teacher's feedback focus and content), is part of a class learning culture conveying powerful messages about learning such as "what is learning" and "how we learn", impacting on children's learning to learn. The literature on social practice theory identifies particular features of the cultural milieu that promotes change. These include the transparency of the socio-political organization of practice, of its content and of the artefacts engaged in practice; the participant's access to resources (both material and symbolic), information and experience and the possibility that a community offers for transferring responsibility to the newcomers (youngest children) (Lave and Wenger 1991). 


\section{Conclusions}

The MEM model seemed to offer relevant pedagogical tools to develop "communities of learning" where children were encouraged to self-regulate their learning and engage in collaborative activities, transforming their leading activity from playing with others to learning with others (Leontev 1981). This study stresses the importance of children's participation in planning and evaluation using assessment for learning to promote learning to learn, going beyond participation and choice.

The results of this study showed that each classroom afforded the children somewhat different experiences and learning cultures. The how, when and why of the tools and activities clearly made a difference. It is important to acknowledge how practices were related with the institutional context and the individual teacher's understanding of the pedagogy.

This does not mean that pedagogical models do not have the power to create learning cultures but the teachers and children, actively re-constructed the cultural tools offered by the pedagogical model (Alexander 2000). As a cultural tool, a pedagogical model, more than just an idealized coherent framework is an emergent epistemology rooted in practice and constantly reflected, mediated and reinvented by its subjects (Peças 2006).

This study provides evidence on how young children can start to direct their learning plans and take responsibility in responding to their problems through active participation in planning and assessment, and it therefore contributes to our understanding of how ECE classrooms can operate as Communities of Learning. In any Communities of Learning, there is always a dual focus: to empower children as learners, using the concept of learning as change in participation, but also to keep a close and critical eye on what the nature of the change is and its relationship with valuable learning. Edwards (2005) calls it "learning as a resourceful action" and argues that it "allows us to examine the processes of learning as well as the outcomes and to consider how they are pedagogically supported" (p. 58). Her argument for research that highlights the cognitive potential of sociocultural approaches to learning can contribute to the research about Learning Cultures in kindergarten (Hodkinson et al. 2008).

The theoretical framework enabled us to study and understand the learning cultures created in the two classrooms by the use of the MEM pedagogy as well as by the structural and process conditions set up by the context (institution; different participants, resources). Further more, we were also able to see how children's change in participation showed in their own control over learning and their learning orientation, linking the situated learning conditions with the observation of cognitive and dispositional learning. 
This research project was co-funded by the "Science and Innovation 2010" Operational Programme (POCI) and by the European Social Fund, ref: SFRH/ BD/ 10606/ 2002.

\section{References}

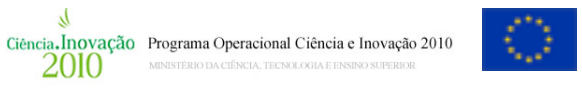

Alexander, R. (2000). Culture and Pedagogy: International Comparisons in Primary Education. Oxford:

Blackwell publishers.

Carr, M. (2001). Assessment in Early Childhood Settings. London: Paul Chapman Publishing.

Claxton, G. (2002). Education for the learning age: a Sociocultural Approach to Learning to Learn. In G. Wells

\& G. Claxton (Eds.), Learning for Life in the 21 st Century (pp. 21-33). Oxford: Blackwell Publishing.

Dweck, C. (1986). Motivational processes affecting learning. American Psychologist, 41(10), 1040-1048.

Dweck, C. S. (2000). Self-theories. Their role in Motivation, Personality and Development. Sussex: Taylor \& Francis.

Edwards, A. (2005). Let's get beyond community and practice: the many meanings of learning by participating. Curriculum Journal, 16(1), 49-61.

Epstein, A. (2003). How Planning and Reflection Develop Young Children's Thinking skills. Young Children, 58(5), 28-36.

Folque, M. A. (2010). Interviewing Young Children. In G. M. Naughton, S. A. Rolfe \& I. Siraj-Blatchford (Eds.), Doing Early Childhood Research: International Perspectives on Theory \& Practice (2nd ed., pp. 239260). Crows Nest: Allen \& Unwin.

Folque, M. A. (2011 in press). Aprender a aprender no Pré-escolar: o modelo pedagógico do Movimento da Escola Moderna. Lisboa: Fundação Calouste Gulbenkian; F. C. T.

Hodkinson, P., Biesta, G., \& James, D. (2008). Understanding Learning Culturally: Overcoming the Dualism Between Social and Individual Views of Learning. Vocations and Learning, 1(1), 27-47.

James, M., Black, P., Carmichael, P., Conner, C., Dudley, P., Fox, A., et al. (2006). Learning How to Learn: tools for schools. London: Routledge.

Kamins, M. and Dweck, C. (1999). Person versus process praise and criticism: implications for contingent selfworth and coping. Developmental Psychology, 35, 835-847.

Leont'ev, A. N. (1981). Problems of the Development of the Mind. Moscow: Progress publishers.

Lave, J., \& Wenger, E. (1991). Situated Learning - Legitimate peripheral participation. Cambridge: Cambridge University Press.

Larkin, S. (2010). Metacognition in Young children. New York: Routledge.

Niza, S. (1996). O modelo curricular de educação pré-escolar da Escola Moderna Portuguesa. In J. OliveiraFormosinho (Ed.), Modelos Curriculares para a Educação de Infância (pp. 138-159): Porto Editora.

Peças, A. (2006). Sérgio Niza: A construção de uma democracia na acção educativa. Educação - Temas e Problemas, 1(1), 147-167.

Poluyanov, Y. A., \& Matiss, T. A. (1999). Development of evaluation at the initial stage of learning activities. In M. Hedegaard \& J. Lompsher (Eds.), Learning activity and development (pp. 249-267). Oxford: Aarhus University Press.

Pramling, I. (1996). Understanding and empowering the child as a learner. In D. Olson \& N. Torrance (Eds.), Handbook of Education and Human Development: New Models of Learning, Teaching and Schooling (pp. $565-$ 592). Oxford: Blackwell.

Rogoff, B. (1998). Cognition as a Collaborative Process. In D. Kuhn \& R. S. Siegler (Eds.), Handbook of child psychology: Cognition, perception, and language (2), (pp. 679-744). New York ; Chichester: John Wiley \& Sons.

Sheridan, S., \& Pramling-Samuelsson, I. (2001) Children's Conceptions of Participation and Influence in Preschool: a perspective on pedagogical quality, Contemporary Issues in Early Childhood, 2(2), 169-194.

http://dx.doi.org/10.2304/ciec.2001.2.2.4

Siraj-Blatchford, I., Sylva, K., Muttock, S., Gilden, R., \& Bell, D. (2002). Researching effective pedagogy in the early years (No. Research report 356). London: Department for Education and Skills.

Siraj-Blatchford, I. (2007). Creativity, Communication and Collaboration: The Identification of Pedagogic Progression in Sustained Shared Thinking. Asia-Pacific Journal of Research in Early Childhood Education, 1(2), 3-23.

Sylva, K. (1992). Conversations in the Nursery: How They Contribute to Aspirations and Plans. Language \& Education, 6(2-4), 141-148.

van Oers, B. (1999). Teaching opportunities in play. In M. Hedegaard \& J. Lompsher (Eds.), Learning activity and development (pp. 269-289). Oxford: Aarhus University Press.

Watkins, C. (2000). Feedback between teachers. In S. Askew (ed.), Feedback for Learning (pp. 65-80). London: Routledge.

Watkins, C. (2001). Learning about learning enhances performance. NSIN Research Matters, 13. 
Watkins, C. (2005). Classrooms as learning communities: a review of research. London Review of Education, 3(1), 47-64.

Wenger, E. (1998). Communities of practice: learning, meaning and identity. Cambridge: Cambridge University Press.

Wertsch, J. V. (1998). Mind as action. New York Oxford: Oxford University Press.

Vygotsky, L. (1978). Mind in Society. Harvard University Press. 